\title{
Geo-Economic Strategy of the European Union: Experience for Ukraine
}

\author{
Nataliya Kostenko, Donetsk National Technical University
}

\begin{abstract}
The cooperation among the states requires that countries adapt their strategies to new terms of interaction when concluding regional trade agreements. Integration priorities are aimed at improving nations' welfare and national competitiveness. The purpose of the article is to identify the areas of economic adaptation based on the world ranking and matrix of geoeconomic strategies development. The matrix being proposed helps countries to identify development strategies in bilateral cooperation and to find the ways to improve trade infrastructure. Descriptive statistics method and index method are used in the article.
\end{abstract}

Keywords: geo-economics, strategy, regional trade agreement, trade policy, matrix, index

\section{INTRODUCTION}

Each country or group of countries forms their own trade policies based on a set of tools and measures that ensure realization of their interests in the global economy. Trade policy mechanism aims at establishing favorable terms of trade being clear to potential partners. Trade policy of a state is formed based on foreign economic cooperation priorities, specialization in production of goods and services, geographical orientation of trade flows and infrastructure opportunities to ensure due supply of competitive products in these markets.

F. List in his research asserts that "International trade, by rousing activity and energy, by the new wants it creates, by the propagation among nations of new ideas and discoveries, and by the diffusion of power, is one of the mightiest instruments of civilization, and one of the most powerful agencies in promoting national prosperity" [1]. Such logic of civilization development proposed by F. List remains relevant nowadays.

Modern strategies of geo-economic development are shaped in accordance with GATT/WTO or integration groups' trade policy and reflect the priorities of international cooperation, as represented in the EU and World Bank program documents [2] [5].

\section{EMPIRICAL STUDY}

General terms of international trade set by the World Trade Organization require adaptation to modern requirements and new trends. On the other hand, countries require well-timed trade policy reforms.

As EU Trade Policy Study Group reports to the new European Commission and Parliament, "WTO progress will never be made on many of the new and future issues unless countries have undertaken necessary reforms before the multilateral process gets rolling. This points to the need for countries to prepare themselves more vigorously for multilateral trade reforms by advancing a domestic reform agenda that can form the basis of WTO commitments at a later stage" [2, p. 26]. In this respect, the EU can act as a locomotive for policy reforms in other countries signing bilateral Preferential Trade Agreements and Free Trade Area Agreements. Changes occurring at the beginning of the third millennium require that the main factors of ensuring competitiveness are investigated and grounded in the context of modern progressive trends. As a result of such research, adaptive strategy of effective operation in the global economic environment is to be built. It is necessary to admit that possibilities of traditional competitiveness factors are reducing gradually and a wide range of new factors are being brought to the fore.

Formation of the integration capacity reflects countries' pursuit of a flexible cooperation aimed at achieving nations' welfare that is the main goal of any integration group. Wellbeing of the nations will always act as the main indicator of geoeconomic development strategy within the group. Therefore, nowadays both bilateral and multilateral agreements are signed within the competence of the WTO. Thereby such agreements serve as a basis for regional cooperation.

The effectiveness of different forms of integration will show itself through the lenses of various aspects of human activity and only the most appropriate ones (in terms of economic, social and political life) will remain. For example, due to the weakening of the EU competitiveness in the global economy, a trading strategy for 2011-2015 became the core of "Europe 2020 " strategy declared in 2010. It was based on the following key priorities [2, p. 36], [3, p. 2-3]:

- An emphasis on concluding on-going multilateral and bilateral trade negotiations, in particular those with the strongest economic potential, as well as on better enforcement of existing agreements, focusing on nontariff barriers to trade;

- Trade opening initiatives for sectors of the future, such as "green" products and technologies, high-tech products and services, and emphasis on international standardization in growth areas in particular;

- Proposals for high-level strategic dialogues with key partners, to discuss strategic issues ranging from market access, regulatory framework, global imbalances, energy and climate change, access to raw materials, to global poverty, education and development. The Strategy will also work to reinforce the Transatlantic Economic Council with the US the High Level Economic Dialogue with China and deepen its relationship with Japan and Russia; 
- Acceleration of negotiations to establish free trade area with Ukraine, MERCOSUR, Gulf Cooperation Council, India, Canada and the Andean countries (prime examples are the recent signing of a free trade agreement between the EU and South Korea and a future agreement with Central America. Singapore, Malaysia and Vietnam (ASEAN) are on the waiting list in the strategic plan);

- Recognizing that the United States, Japan, China and Russia are key strategic trade partners of the EU, the latter emphasizes the measures to counter protectionist barriers and restrictions on raw materials exports in China and Russia that create the potential for tension in trade and economic relations with these countries. Russia's entry into the WTO "remains a key challenge in the short term for EU trade policy."

It can be observed that the EU relies on large countries as well as regional groupings, which play a significant role in transformation of relations among the countries. The EU geoeconomic position as to free trade zones is expressed in terms of "expanded" regionalism strategy [4, p. 26]. The EU stakes on geographic expansion, which allows improving the terms of trade fragmentation of European transnational corporations.

Combining countries' efforts within the scope of regional integration involves industry modernization to increase export potential. Competitiveness recovery takes place in the industries with higher added value. Partnership of regional block countries is conductive to the efficient flow of investment in the sectors that provide exports, improving the investment potential.

Globalization processes impose certain requirements to be met while implementing integration strategies and converting strategy pattern to geo-economic sphere. Geo-economics serves as a prerequisite for the restoration of the EU positions lost during the crisis. By the definition of R. Youngs, geoeconomics denotes the use of statecraft for economic ends; a focus on relative economic gain and power; a concern with gaining control of resources; the enmeshing of state and business sectors; and the primacy of economic security over other forms of security [6, p. 14]. Thus, the gradual integration path defined by the nature of trade policy allows establishing joint production facilities and making successive steps to expand cooperation with other countries. In this regard each country tends to implement certain strategies based on economic rather than political expediency.

Ukraine's long-term uncertainty in choosing integration vectors has slowed export growth and reduced the possibility of its diversification.

The level of exports complexity serves not only as an indicator of advantage over another country at any given time. According to Hausmann, Hwang, and Rodrik, complexity level of country's export basket can be a good signal of future growth prospects [7].

Current geo-economic space becomes increasingly complex and requires new approaches to assessing its potential. In this regard geo-economics as a scientific paradigm places new imperatives for modern society development. Competitiveness is one of the main factors of sustainable development. But due to the rapid scientific and technological progress and new opportunities for the countries to utilize it efficiently, the list of new externalities is expanded annually. Today's EU trade policy in international relations focuses on trade partners' relationship forming domestic and foreign trade streams. That is why a lot of international organizations monitor international trade flows' movement to retrace how recommendations proposed in the course of multilateral negotiations are implemented. As a result, a diversified scoring system of trade policy evaluation was developed. This trade policy assessment methodology is based on rating the system that is carried out by various international institutions.

Implementation of the country's strategic interests is based on the introduction of information and communication technologies (ICT) in public administration sphere. In the process of international integration countries stick to the development of modern information and communication infrastructure and its constant upgrade due to onrush of technology. It allows the countries to set up a new electronic communications networks for the public, simplify management of business processes as well as standardize cross-border operations by implementing electronic forms of documents and payment, etc. Therefore, the countries demonstrating a high level of ICT are more competitive as ICTs contribute to economic development. Other ways how ICTs increase competitiveness are by virtue of improved government efficiency and transparency, advance in labor market skills and productivity, stimulating information flow and resource interchange that readjust education quality.

Within the scope of our investigation, the greatest scientific interest is turned to indices that reflect the nature of trade policy in particular. For example, since 2008 the World Economic Forum announces The Enabling Trade Index (ETI) that is composed of nine pillars of enabling trade. These are:

1. Domestic and foreign market access:

a. domestic market access (DMA);

b. foreign market access (FMA).

2. Efficiency of customs administration (ECA).

3. Efficiency of import-export procedures (EIEP).

4. Transparency of border administration (TBA).

5. Availability and quality of transport infrastructure (AQTI).

6. Availability and quality of transport services (AQTS).

7. Availability and use of ICTs (AICT).

8. Regulatory environment (RE).

9. Physical security $[8$, p. 6]

The Enabling Trade Index has a fairly standardized nature that indicates the score along with rating where each sub-index is scored from 0 to 7 points. More than 500 indicators are to be used in ETI calculation. The proposed Index assesses the position of each country' in trade policy implementation objectively and reflects reform trends as well.

In the World Bank rating system, the EU countries' internal trade policies rating is identical to external one and despite unified trade policy and common external terms each country has different potential (Table 1).

Rating presented in Table 1 provides a complete picture of the terms of trade operations and the EU ability to cooperate for the sake of trade infrastructure development. 
A number of countries within the EU rank within the top 20 of the ETI rankings, reflecting their well-developed infrastructures, widely available transport services, and efficient border administrations. However, their trade performance is constrained by the overly restrictive common trade policy of the European Union [8, p.23].

TABLE I

THE ENABLING TRADE INDEX 2010-2012 RANKINGS

\begin{tabular}{|c|c|c|c|c|c|c|c|c|c|c|c|c|}
\hline & \multirow{2}{*}{ 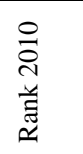 } & \multirow{2}{*}{ 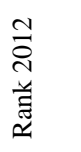 } & \multicolumn{10}{|c|}{ Enabling Trade Index - 2012} \\
\hline & & & 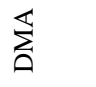 & $\sum_{\Sigma}^{\mathbb{I}}$ & 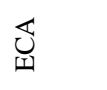 & $\frac{\text { 至 }}{\underline{\mid r}}$ & $\underset{\theta}{\mathbb{9}}$ & $\underset{\&}{2}$ & $\stackrel{\mathscr{\sigma}}{\sigma}$ & $\stackrel{U}{Z}$ & $\frac{1}{\alpha}$ & 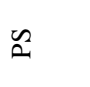 \\
\hline Austria & 14 & 15 & 4.83 & 2.06 & 5.88 & 5.56 & 5.51 & 5.69 & 5.27 & 5.67 & 4.74 & 6.02 \\
\hline Belgium & 24 & 21 & 4.83 & 2.06 & 4.57 & 5.28 & 5.55 & 5.69 & 5.42 & 5.49 & 4.7 & 5.84 \\
\hline Bulgaria & 78 & 74 & 4.83 & 2.06 & 4.07 & 4.47 & 3.11 & 4.24 & 3.84 & 4.51 & 3.38 & 4.1 \\
\hline Cyprus & 31 & 37 & 4.83 & 2.06 & 4.44 & 5.47 & 4.9 & 5.02 & 4.14 & 4.35 & 4.62 & 5.61 \\
\hline Czech Republic & 42 & 41 & 4.83 & 2.06 & 5.28 & 4.94 & 3.72 & 5.12 & 4.01 & 5 & 3.7 & 5.16 \\
\hline Denmark & 3 & 3 & 4.83 & 2.06 & 5.91 & 6.22 & 6.53 & 6.07 & 4.89 & 6.29 & 5.27 & 6.28 \\
\hline Estonia & 23 & 26 & 4.83 & 2.06 & 5.7 & 5.94 & 5.18 & 4.63 & 3.85 & 5.69 & 4.56 & 5.79 \\
\hline Finland & 12 & 6 & 4.83 & 2.06 & 5.11 & 6.12 & 6.41 & 5.76 & 4.85 & 6.2 & 5.39 & 6.54 \\
\hline France & 20 & 20 & 4.83 & 2.06 & 5.23 & 5.94 & 5.15 & 6.27 & 5.18 & 5.81 & 4.72 & 5.33 \\
\hline Germany & 13 & 13 & 4.83 & 2.06 & 5.16 & 5.84 & 5.6 & 5.99 & 5.56 & 5.82 & 4.85 & 5.77 \\
\hline Greece & 55 & 67 & 4.83 & 2.06 & 3.47 & 4.6 & 3.32 & 5.17 & 3.87 & 4.38 & 3.46 & 4.73 \\
\hline Hungary & 49 & 47 & 4.83 & 2.06 & 5.59 & 4.82 & 4.05 & 3.72 & 4.45 & 4.96 & 3.73 & 5.17 \\
\hline Ireland & 22 & 21 & 4.83 & 2.06 & 5.94 & 5.57 & 5.86 & 5.43 & 4.86 & 4.95 & 4.54 & 5.97 \\
\hline Italy & 51 & 50 & 4.83 & 2.06 & 3.95 & 5.12 & 3.71 & 5.08 & 4.83 & 5.01 & 3.58 & 5.01 \\
\hline Latvia & 46 & 52 & 4.83 & 2.06 & 4.46 & 5.49 & 3.82 & 4.69 & 3.53 & 4.81 & 3.73 & 5.09 \\
\hline Lithuania & 41 & 45 & 4.83 & 2.06 & 4.52 & 5.24 & 4.23 & 4.34 & 3.84 & 5.44 & 3.62 & 5.29 \\
\hline Luxembourg & 9 & 10 & 4.83 & 2.06 & 4.63 & 5.34 & 6.16 & 6.01 & 5.29 & 6.04 & 5.46 & 6.04 \\
\hline Netherlands & 10 & 7 & 4.83 & 2.06 & 5.97 & 5.84 & 6.18 & 5.85 & 5.58 & 6.32 & 5.22 & 5.72 \\
\hline Poland & 58 & 48 & 4.83 & 2.06 & 4.46 & 5.2 & 4.53 & 3.8 & 4.31 & 4.6 & 3.94 & 5.29 \\
\hline Portugal & 36 & 35 & 4.83 & 2.06 & 3.84 & 5.53 & 4.96 & 5.55 & 4.54 & 5.04 & 3.89 & 5.67 \\
\hline Romania & 54 & 69 & 4.83 & 2.06 & 4.43 & 4.71 & 3.56 & 3.41 & 3.98 & 4.18 & 3.4 & 4.77 \\
\hline Slovak Republic & 47 & 55 & 4.83 & 2.06 & 4.94 & 4.38 & 3.81 & 4.61 & 4.32 & 4.71 & 3.6 & 5.04 \\
\hline Slovenia & 35 & 33 & 4.83 & 2.06 & 5.45 & 5.09 & 4.78 & 5.09 & 4.37 & 5.09 & 3.72 & 5.75 \\
\hline Spain & 32 & 31 & 4.83 & 2.06 & 5.42 & 5.02 & 4.9 & 6.03 & 5.18 & 5.08 & 3.99 & 5.46 \\
\hline Sweden & 4 & 4 & 4.83 & 2.06 & 6.34 & 6.22 & 6.48 & 5.37 & 4.82 & 6.08 & 5.54 & 6.22 \\
\hline United Kingdom & 17 & 11 & 4.83 & 2.06 & 5.96 & 5.83 & 5.62 & 5.91 & 5.32 & 6.27 & 4.98 & 5.34 \\
\hline Mean* & - & - & 4.83 & 2.06 & 5.03 & 5.38 & 4.91 & 5.17 & 4.62 & 5.3 & 4.32 & 5.5 \\
\hline Minimum* & - & - & 4.83 & 2.06 & 3.47 & 4.38 & 3.11 & 3.41 & 3.53 & 4.18 & 3.38 & 4.1 \\
\hline Maximum* & - & - & 4.83 & 2.06 & 6.34 & 6.22 & 6.53 & 6.27 & 5.58 & 6.32 & 5.54 & 6.54 \\
\hline Std.Dev.* & - & - & 0.0 & 0.0 & 0.77 & 0.53 & 1.05 & 0.79 & 0.62 & 0.67 & 0.72 & 0.55 \\
\hline Ukraine & 81 & 86 & 5.47 & 3.24 & 2.78 & 3.37 & 2.40 & 4.34 & 3.42 & 3.98 & 2.86 & 4.46 \\
\hline
\end{tabular}

Source R. Lawrence, M. Hanouz, S. Doherty, J. Moavenzadeh. The Global Enabling Trade Report 2012. Reducing Supply Chain Barriers - Geneva: World Economic Forum. - 2012. - 382 p. P.12-19

* Calculated by means of Statistica 8.0 
Data from Table 1 reflect time history of ETI in comparison with 2010.

In fact, countries of last two expansion waves have improved their positions. For example, Bulgaria and Poland have shifted by 4 and 10 points correspondingly. On the other hand, Greece and Romania lost their positions significantly, which is demonstrated by decrease of 12 and 15 points correspondingly. In comparison with the EU countries, Ukraine ranks at a much worse position and its average value is inferior to the EU average (Figure 1).

From Figure 1 we can see that Ukraine's integration into the European vector must be followed by efforts to increase transparency of customs procedures and import / export efficiency together with infrastructure improvements. In the recent years Ukraine is actively pursuing reforms in this direction and comparison of its positions with Poland according to "Doing Business 2012" [9, P. 189, 202] makes it possible to identify the key steps (Table 2).

Thus Ukraine still has a lot to do to reduce cost and time of export-import operations.

Fig. 1. Comparison of the EU and Ukrainian ETI (developed by the author)

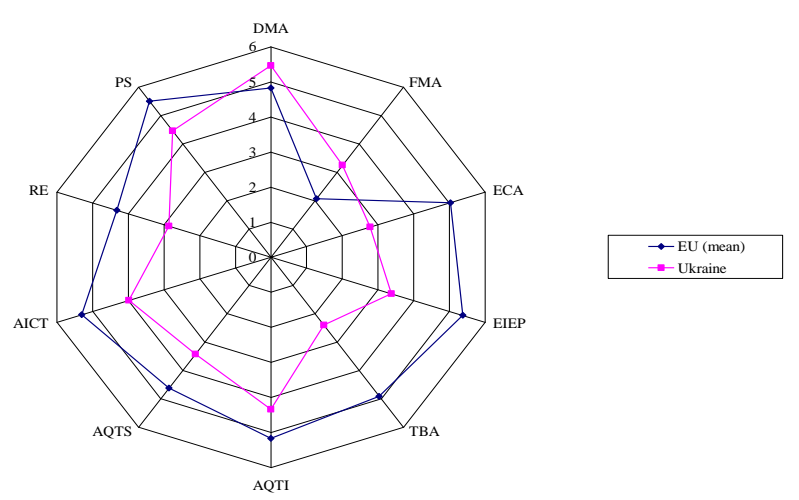

Ukraine's aspiration for European integration is based on the implementation of the trade policy adjusted for specific industries. The policy directs the governments to developing key indicators to guarantee economic growth on the basis of the balance between aggregate demand and supply. Some countries develop export areas by means of stimulation of investments in production, while other countries channel their resources to the expansion of domestic consumption together with involvement of the imported reserve.

TABLE II

COMPARISON OF POSITIONS OF POLAND AND UKRAIN

\begin{tabular}{|l|l|l|l|l|}
\hline Pillars & Units & Poland & Ukraine & Deviation \\
\hline $\begin{array}{l}\text { Trading across } \\
\text { borders }\end{array}$ & rank & 50 & 145 & -95 \\
\hline Documents to export & number & 5 & 6 & -1 \\
\hline Time to export & days & 17 & 30 & -13 \\
\hline Cost to export & US\$ per container & 1,050 & 1,865 & -815 \\
\hline Documents to import & number & 5 & 8 & -3 \\
\hline Time to import & days & 16 & 33 & -17 \\
\hline Cost to import & US\$ per container & 1.025 & 2.155 & -1130 \\
\hline
\end{tabular}

Developed on the basis of: 2012 Doing Business Smarter Regulations for Small and Medium-Size Enterprises. 10th Edition. - Washington: International Bank for Reconstruction and Development The World Bank, 2013.
Regarding the definition of geo-economic strategies, a matrix that consists of six quadrants has been developed.

To determine the interval values of quadrants, the author has selected RCA [10] and RSCA [11] indicators according to HS 2007 EU countries based on WITS database [12].

In his empirical studies D.Worrall [13] analyzes the positions of EU countries commodity groups considering the perspective of RCA, Grubel-Lloyd and other indices that are considered separately. After considering such paradigm, the author has proposed an approach that allows determining commodity group position in two-dimensional terms, which makes the analysis more meaningful from a practical point of view.

The curve illustrating logarithmic function of commodity group distribution (Figure 2) demonstrates the result of index calculation. It also shows the reason why interval values of quadrants in the matrix vary. Substitution of values into the equation $y=0.4332 \ln (x)+0.0015$ leads to setting quadrant intervals of geo-economic strategies matrix (Figure 3) where intervals of IV, V and VI quadrant have the lowest values.

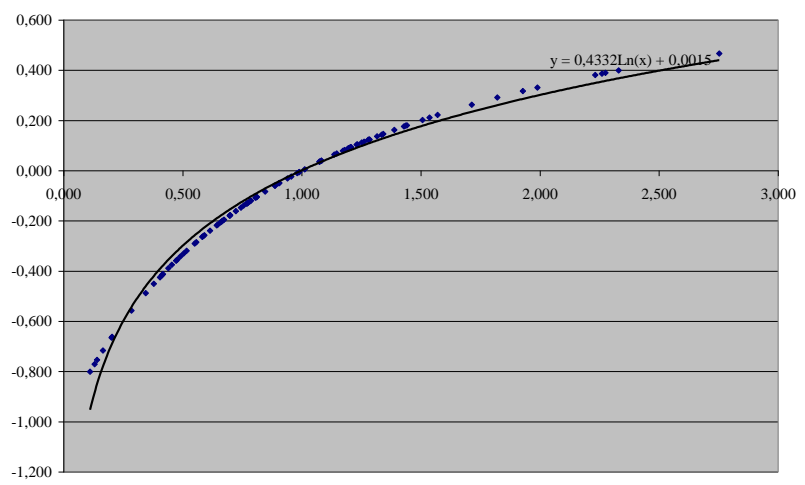

Fig. 2. Logarithmic function of the EU commodity group distribution (developed by the author)

The values of $R C A$ and $R S C A$ indices for the EU and Ukraine are calculated for the year 2012 based on Trade Map data.

The EU countries based matrix demonstrates absence of product groups according to export expansion strategy. This indicates termination of trade expansion by regional grouping as a whole as a result of strong domestic market shaping by the EU by measn of intra-regional export specialization and intersectoral cooperation strategy.

Only two product groups available in V quadrant of the EU matrix testify that European countries have used their technological advantages and adopted best world production practices.

\begin{tabular}{|c|c|c|}
\hline $\begin{array}{c}\text { III Strategy of export } \\
\text { orientation } \\
0.5 \leq R C A \leq 0.99 \\
0 \leq R S C A<0.3 \\
\text { Commodity groups: } \\
03,08,09,10,12,13,14,15, \\
17,25,28,31,42,47,50,53, \\
54,55,58,60,61,62,63,65, \\
71,74,75,80,84,90,91,92, \\
94,95,97\end{array}$ & $\begin{array}{c}\text { II Strategy of export } \\
\text { specialization } \\
1 \leq R C A \leq 2.99 \\
0.3 \leq R S C A<0.6 \\
\text { Commodity groups: } \\
01,02,04,05,06,07,11,16, \\
18,19,20,21,22,23,24,29, \\
30,32,33,34,35,36,37,38, \\
39,40,41,43,44,45,48,49, \\
51,56,57,59,64,66,68,69, \\
70,72,73,76,77,78,81,82, \\
83,85,86,87,89,93,96\end{array}$ & $\begin{array}{l}\text { I Strategy of } \\
\text { export expansion } \\
3 \leq R C A<\infty \\
0.6 \leq R S C A<1 \\
\text { Commodity } \\
\text { groups: - }\end{array}$ \\
\hline
\end{tabular}




\begin{tabular}{|c|c|c|}
\hline VI Strategy of import and & V Strategy of & IV Strategy of \\
import-substituting & emulation & inter-branch \\
$0 \leq R C A \leq 0.19$ & $0.2 \leq R C A \leq 0.29$ & cooperation \\
$-1 \leq R S C A<-0.9$ & $-0.9 \leq R S C A<-0.7$ & $0.3 \leq R C A \leq 0,49$ \\
Commodity groups: & Commodity groups: & $-0.7 \leq R S C A<0$ \\
26 & 46,67 & Commodity \\
& & groups: \\
& & $27,52,79,88$ \\
\hline
\end{tabular}

Fig. 3. Matrix of the EU geo-economic strategies development (developed by the author)

At the same time, group 26 explicitly requires imports of mineral products such as iron ore.

Identifying Ukraine's strategic choice, World Bank experts emphasize the EU markets priority for the Ukrainian export [5, p. 57].

The cooperation of the EU countries with Ukraine in commodity markets calls for modernization of the infrastructure and adoption of new technological regulations. According to RCA and RSCA indices calculated for Ukraine and the EU in 2012, commodity groups of the first priority for Ukraine in the European market are: 10 - cereals, 12 - oil seed, oleagi fruits, miscell grains, 15 - animal fats, oils, their cleavage products, 23 - residues, waste from the food industries, 25 - salt, sulphur, earth, stone, plastering materials, 26 - ores, slag and ash, 44 - wood and articles of wood, $72-$ iron and steel, 85 - electrical, electronic equipment (Table 3).

Studying the Latvian experience for Ukraine and basing on comparative matrix of geo-economic strategies development (Table 3), we can observe that in 2012 on the world market Latvia and Ukraine implemented the same expansionist potential quantifiable, which accounted for 11 commodity groups.

Meanwhile, the cooperation within the EU does not interfere with Latvia's opportunities to realize its expansionist potential in other parts of the world where it comes to the fore in the production of: live animals (01), products of the milling industry, malt, starches (11), meat, fish or crustaceans (16), beverages, spirits and vinegar (22) iron and steel (72). Quadrants II and III, including the strategy of export specialization and export orientation, show that the EU countries are the main trading partners for Latvia in terms of world trade.

TABLE III

COMPARISON GEO-ECONOMIC STRATEGY DEVELOPMENT MATRIXES OF LATVIA AND UKRAINE FOR 2012

\begin{tabular}{|c|c|c|c|c|c|}
\hline \multirow[t]{2}{*}{ Matrix Quadrants } & \multirow{2}{*}{$\begin{array}{l}\text { Types of } \\
\text { Strategies }\end{array}$} & \multicolumn{2}{|l|}{ Latvia and } & \multicolumn{2}{|l|}{ Ukraine and } \\
\hline & & World & EU & World & EU \\
\hline $\begin{array}{l}\text { I } \\
3 \leq R C A<\infty \\
0,6 \leq R S C A<1\end{array}$ & $\begin{array}{l}\text { Strategy of } \\
\text { export } \\
\text { expansion }\end{array}$ & $\begin{array}{l}01,04,10,11,12,16,22,44 \\
49,66,72\end{array}$ & $03,04,10,12,44,46$ & $\begin{array}{l}10,12,15,18,23,25,26 \\
28,31,72,86\end{array}$ & $\begin{array}{l}10,12,15,23,25,26,31,44 \\
72,86\end{array}$ \\
\hline $\begin{array}{l}\text { II } \\
1 \leq R C A \leq 2,99 \\
0,3 \leq R S C A<0,6\end{array}$ & $\begin{array}{l}\text { Strategy of } \\
\text { export } \\
\text { specialization }\end{array}$ & $\begin{array}{l}03,06,08,09,17,18,19,20 \\
21,23,24,25,30,32,33,34 \\
38,43,48,58,60,62,63,68 \\
70,73,74,86,94\end{array}$ & $\begin{array}{l}01,08,09,11,14,16,17 \\
19,23,25,27,34,43,49 \\
53,58,60,61,62,63,68 \\
70,72,73,74,85,94\end{array}$ & $\begin{array}{l}04,11,17,19,20,24,32 \\
44,48,66,69,73,81\end{array}$ & $\begin{array}{l}14,17,20,28,35,36,41,62 \\
63,81,85,89\end{array}$ \\
\hline $\begin{array}{l}\text { III } \\
0 \leq R S C A<0,3 \\
0,5 \leq R C A \leq 0,99\end{array}$ & $\begin{array}{l}\text { Strategy of } \\
\text { export } \\
\text { orientation }\end{array}$ & $\begin{array}{l}02,05,07,15,35,37,39,40 \\
46,53,54,56,61,64,65,69 \\
76,78,83,85,87,95,96\end{array}$ & $\begin{array}{l}02,05,07,15,18,20,21 \\
22,24,31,32,35,37,38 \\
39,40,47,48,52,56,64 \\
65,66,67,76,78,86,87 \\
95,96\end{array}$ & $\begin{array}{l}02,07,08,21,22,34,35 \\
36,41,49,62,68,70,78 \\
83,88,89,94\end{array}$ & $\begin{array}{l}08,27,32,43,46,61,64,73 \\
88\end{array}$ \\
\hline $\begin{array}{l}\text { IV } \\
0,3 \leq R C A \leq 0,49 \\
-0,7 \leq R S C A<0\end{array}$ & $\begin{array}{l}\text { Strategy of } \\
\text { inter-branch } \\
\text { cooperation }\end{array}$ & $\begin{array}{l}14,27,31,42,47,51,55,57 \\
59,79,82,84,89,90\end{array}$ & $\begin{array}{l}30,33,42,51,69,79,82 \\
83,84,91\end{array}$ & $\begin{array}{l}14,16,33,39,56,57,59 \\
63,64,84,85\end{array}$ & $05,07,18,42,65,70,74,76$ \\
\hline $\begin{array}{l}\mathrm{V} \\
0,2 \leq R C A \leq 0,29 \\
-0,9 \leq R S C A<-0,7\end{array}$ & $\begin{array}{l}\text { Strategy of } \\
\text { emulation }\end{array}$ & $29,41,52,92$ & $\begin{array}{l}06,28,41,57,59,71,89 \\
90\end{array}$ & $\begin{array}{l}27,29,38,40,43,74,76 \\
79,95\end{array}$ & $\begin{array}{l}11,19,21,29,48,53,58,60 \\
68,78,83,94\end{array}$ \\
\hline $\begin{array}{l}\text { VI } \\
0 \leq R C A \leq 0,19 \\
-1 \leq R S C A<-0,9\end{array}$ & $\begin{array}{l}\text { Strategy of } \\
\text { import and } \\
\text { import- } \\
\text { substituting }\end{array}$ & $\begin{array}{l}13,26,28,36,45,50,67,71 \\
75,80,81,88,91,93,97\end{array}$ & $\begin{array}{l}13,26,29,36,45,50,54 \\
55,75,80,81,88,92,93 \\
97\end{array}$ & $\begin{array}{l}01,03,05,06,09,13,30 \\
37,42,45,46,47,50,51 \\
52,53,54,55,58,60,61 \\
65,67,71,75,80,82,87 \\
90,91,92,96,97\end{array}$ & $\begin{array}{l}01,02,03,04,06,09,13,16 \\
22,24,30,33,34,37,38,39 \\
40,45,47,49,50,51,52,54 \\
55,56,57,59,66,67,69,71 \\
75,79,80,82,84,87,90,91 \\
92,95,96,97\end{array}$ \\
\hline
\end{tabular}

(developed by the author)

The importance of trade with the EU partners is indicated by the duplication of commodity groups in quadrants II and III. There is a potential for the application of the EU experience in Latvia. Particularly it comes to growing live trees, other plants, bulbs, roots (06 product groups), manufacture of inorganic chemicals, compounds of precious metals (28), manufacture of carpets and other textile floor covering (57), production and processing of natural, cultured pearls, precious stones (71), production of ships, boats and floating structures (89) and the manufacture of optical, photo, cinema equipment and parts (90).

As we can see, Ukraine compared with Latvia does not fully realize the potential of export specialization and export 
orientation strategies. The implementation of export orientation strategy for Ukraine with the EU countries is possible in growing edible fruits and nuts (08). This market becomes of special importance in view of anti-dumping duties introduced by Turkey considering walnuts of Ukrainian origin.

Cross-industry collaboration opportunities could further be highlighted by the production of products of animal origin (05), growing of edible vegetables and certain roots $(07)$, production of cocoa and cocoa preparations (18), articles of leather, saddlery, harne manufacture (42), manufacture of headgear and parts thereof (65) manufacture of glass and glassware (70), manufacture of aluminium and copper and articles thereof (74 and 76 commodity group).

Quadrant V implies emulation of experience of other countries. While studying the European experience, Ukraine should pay attention to the implementation of technical regulations and standards of the EU in the manufacture of products of the milling industry, malt, starches (11) and prep. of cereal, flour, starch, milk (19), the production of miscellaneous edible preparations (21), the production of organic chemicals (29), the production of paper and paperboard (48), production of other vegetable textile fibers, special woven fabrics, tufted textile fabrics and knitted or crocheted fabrics (53, 58 and 60 commodities), manufacture of art of stone, plaster, cement (68), production of lead and articles thereof (78) and production of furniture, bedding, mattress (94). Dairy products from Ukraine are well positioned on the world market in terms of export specialization strategy but there is no demand for our products in the EU. There are three reasons for that:

1) Products do not comply with technical regulations;

2) Import duty on commodity group number 04 in the EU ranges from 0 to $164.8 \%$ [14, p. 36];

3) The EU subsidizes the production of agricultural products from the budget.

The situation is similar with the products of the flour-milling industry (11 commodity group).

As a result, based on the data of Table 3 we can see that cooperation with the EU countries is extremely important for Ukraine because the structure of merchandise exports in 2012 (as in the previous years as well) was absolutely unbalanced. The conclusion of the Association Agreement between Ukraine and the EU free trade zone will give us the ability to export products to the EU at preferential import duties. Moreover, it will help to modernize Ukrainian production to meet the technical regulations and therefore produce better products. Ukraine's participation in free trade zone with the EU will help to avoid the use of non-tariff barriers.

On the other hand, this list may be expanded annually through cooperation in the format of FTA Association Agreement that is urgent for Ukraine.

\section{CONCLUSUONS}

With the formation of the new geo-economic space for the sake of raising competitiveness each country has to go through integration. Countries should determine the integration vector more accurately, given the economic level of individual industries development, political goals, nation mentality, etc.
Incremental change from one form of integration to another shall be governed by a clear schedule and adherence to integration terms. Interaction between Ukraine and the EU is based on financial viability of the collaboration with geographically close countries and potentially expansive market.

\section{REFERENCES}

[1] List, F. National System of Political Economy. [Online]. Available: http://www.economics.kiev.ua/index.php?id=613\&iew=article

[2] A Modern Trade Policy for The European Union. A report to the new European Commission and Parliament from the EU Trade Policy Study Group. [Online]. Available: http://www.ecipe.org/static/pdf/a-moderntrade-policy-for-the-european-union.pdf

[3] EU announces acceptance trading strategy with countries outside the EU, for the period until 2015. P.2-3. [Online]. Available:

http://www.salans.com/enGB/sitecore/content/Salans/Global/Items/Publi cation/2010/ /media/Assets/Salans/Publications/2010/20101115EU\%20 Announces\%20OutwardFocused\%20Trade\%20Strategy\%20RUS.ashxht tp://eurlex.europa.eu/LexUriServ/LexUriServ.do?uri=COM:2010:2020: FIN:EN:PDF

[4] The European Union Trade Policy 2013. European Commission. Trade [Online]. Available: http://trade.ec.europa.eu/doclib/docs/2011/august/ tradoc_148181.pdf $33 \mathrm{p}$.

[5] Ukraine. Memorandum of economic development. Strategic choice for accelerating growth and support. Україна. Memorandum pro ekonomičnij rozvitok. Strategičnij vibir ŝodo priskorennâ ta pidtrimki zrostannâ. Report № 55895-UA. - Poverty Reduction and Economic Management Department (ECA PREM). Document of the World Bank, 2010. - $120 \mathrm{c}$.

[6] Challenges for European Foreign Policy in 2012. What kind of geoeconomic Europe? Editor by Martiningui A., Youngs R. - Madrid: FRIDE, 2011. - p. 14.

[7] Hausmann, R., Hwang ,J., Rodri, D. What You Exports Matters. Journal of Economic Growth. 2007, Vol. 12 No. 1 pp. 1-25. http://dx.doi.org/10.1007/s10887-006-9009-4

[8] Lawrence, R., Hanouz, M., Doherty, S., Moavenzadeh J. The Global Enabling Trade Report 2012. Reducing Supply Chain Barriers - Geneva: World Economic Forum. - 2012. - 382 p.

[9] 2012 Doing Business Smarter Regulations for Small and Medium-Size Enterprises. 10th Edition. - Washington: International Bank for Reconstruction and Development The World Bank, 2013

[10] Balassa, B. Trade liberalization and "revealed" comparative advantage. The Manchester School of Economics and Social Studies, 1965, Vol. 33, No. 2, pp. 99-123.

[11] Laursen, K. Revealed comparative advantage and the alternatives as measures of international specialization, DRUID Working Paper, 1998, No. 98-30, Danish Research Unit for Industrial Dynamics (DRUID).

[12] Worrall, D. Revealed Comparative Advantage and Intra-Industry Trade. At the Crossroads of The European Union and The Commonwealth of Independent States. - LAP Lambert Academic Publishing, 2012. 380 p.

[13] WITS [Online]. Available: http://wits.worldbank.org/WITS/WITS/ WITSHELP/Content/Utilities/e1.trade_indicators.htm

[14] Trade Policy Review/ Report by the Secretariat EUROPEAN COMMUNITIES 2011 [Online]. Available: http://www.hse.ru/data/ 2011/11/29/1271097872/EU\%202011\%20-\%20s248.pdf, P. 36.

Nataliya Kostenko holds $\mathrm{PhD}$ in economics (2002). Having graduated from Donetsk State University of Economics and Trade named after M.I. TuganBaranovsky in 1998, she has a 16 years teaching and scientific experience. Scope of scientific interests: international economy, methodology of geoeconomical analysis, management and marketing strategies.

Publications: 71 research papers and 3 textbooks.

Current work: Associate Professor at the Donetsk National Technical University, Donetsk, Ukraine.

Address: Universitetskaya Str. 108/20, Donetsk, Ukraine

Telephone and e-mail address: +380 501930501; nvk@telenet.dn.ua 
Natālija Kostenko. ES geoekonomiskā stratēgiija: Ukrainas pieredze

Mūsdienu apstākḷos valstu sadarb̄ibas pakāpi nosaka tirdzniecības politika, kas atspoguḷo valsts rūpnieciskās intereses. Rezultātā tirdzniecības politika ḷauj veidot valstu un regionālo apvienību ǵeoekonomiskās attīstības stratēǵiju. Autore veica ES valstu un Ukrainas salīdzinošo analīzi, pamatojoties uz valstu iesaistīšanas globālajā tirdzniecībā indeksu (Enabling Trade Index). Ar ES valstu apakšindeksu aprakstošās statistikas palīdzību atklātas novirzes attiecībā uz Ukrainu. Tāpēc Ukrainas integrācijas ceḷā uz ES jādarbojas šādos virzienos: jāveicina muitas darba „caurspīd̄̄gums”, jāpaaugstina eksporta/importa procedūru efektivitāte, jāuzlabo infrastruktūra. Pamatojoties uz Polijas un Ukrainas piemēru, atspoguḷotas eksporta/importa operāciju rādītāju atškirīības. Rakstā izstrādāta un piedāvāta ǵeoekonomiskās attīstības stratẹgijas noteikšanas matricas metode, kuras pamatā ir B. Balassa (RCA) salīdzinošo priekšrocību indeksi un K. Laursena (RSCA) simetrisko salīdzinošo priekšrocību indeksi. To indeksu aprēḳini, kas rakstā ir izlaisti to lielo apjomu dēl, veikti, pamatojoties uz Trade Map datiem. Pamatojoties uz ES preču grupas sadales logaritmiskajām funkcijām, noteikts matricas I kvadranta intervāls. 2011. gadā autore izstrādāja ES valstu attīstības ǵeoekonomisko stratẹgiju, kur atspoguḷotas šādas stratēgeijas: eksporta ekspansija, eksporta specializācija, eksporta orientācija, starpnozaru sadarb̄ība, emulācijas stratēǵija un importa aizvietošanas vai importa stratêgija. Aprēḳināti Ukrainas un ES stratēǵiskās sadarbības virzieni pa atsevišķām preču grupām.

Наталия Костенко. Геоэкономические стратегии развития стран Европейского Союза: опыт для Украины

В современных условиях степень сотрудничества стран определяется торговой политикой, которая отражает промышленные интересы государств. В результате торговая политика позволяет формировать стратегии геоэкономического развития стран и региональных объединений. Автором проведен сравнительный анализ стран ЕС и Украины на основе Индекса вовлечения стран в глобальную торговлю (Enabling T|внутренней|rade Index). C помощью описательной статистики субиндексов стран ЕС выявлены отклонения по Украине. Поэтому на пути интеграции в ЕС, Украине необходимо работать в направлении повышения прозрачности таможенных органов и эффективности процедур экспорта/импорта, совершенствования инфраструктуры. На основе примера Польши и Украины показаны расхождения по показателям экспортно-импортных операций. В статье разработан и предложен матричный метод определения стратегий геоэкономического развития, в основу которого положены индексы выявленных сравнительных преимуществ Б.Балассы (RCA) и индекса выявленных симметричных сравнительных преимуществ К.Лаурсена (RSCA). Рассчеты индексов, которые опущены в статье из-за значительных объемов, проведены на основе базы данных Trade Мар. На основе логарифмической функции распределения товарных групп ЕС определен нижний интервал I-го квадранта матрицы. Автором разработана матрица стратегий геоэкономического развития стран ЕС в 2011 году, в которой отражены стратегии: экспортной экспансии, экспортной специализации, экспортной ориентации, межотраслевого сотрудничества, стратегия эмуляции и стратегия импортозамещения или импорта. Рассчитаны направления стратегического сотрудничества Украины с ЕС по отдельным товарным группам. 